\title{
EFFECTS OF DIETARY CONCENTRATION LEVELS ON FEED INTAKE AND NUTRIENTS DIGESTIBILITY IN CROSSBRED BEEF CATTLE
}

\author{
Nguyen Binh TRUONG 1,2 \\ 1Department of Animal and Veterinary Sciences, An Giang University, An Giang, Vietnam \\ 2Vietnam National University Ho Chi Minh City, Vietnam \\ অmail: nbtruong@agu.edu.vn; (D) ORCiD: 0000-0003-2056-3479 \\ Supporting Information
}

ABSTRACT: The objective of the present study was to evaluate different concentration levels on the feed intake and nutrient digestibility of different beef cattle breeds. Twenty beef cattle (13 months of age) were allocated in a group of Latin square design $4 \times(5 \times 5)$. The first factor was cattle breeds (Brahman, Black Angus, Charolais, and Red Angus). Furthermore, the concentrate feed levels were 0, 0.5, 1.0, 1.5 and 2.0 $\mathrm{kg}$ /animal/day, corresponding to $\mathrm{C0}, \mathrm{C0.5}, \mathrm{C1.0}, \mathrm{C1.5}$, and $\mathrm{C2.0}$ as treatments. The basal diet was fresh Elephant grass $(5 \mathrm{~kg} / \mathrm{d})$ and ad libitum rice straw. Beef cattle were adapted to ration for 7 days followed by 7 days of sample collection and dissecting samples. The results showed that dry matter intake $(\mathrm{kg} / 100 \mathrm{~kg}$ live weight) was significantly different among cattle breeds, the highest value was for Charolais (2.37 kg) and the lowest value was for Brahman cattle $(2.15 \mathrm{~kg})$. The dry matter digestibility of Brahman $(62.0 \%)$ was higher than Black Angus (53.1\%), Charolais (53.3.7\%), and Red Angus (54.7\%). However, the daily weight gain of Brahman was lower than Black Angus, Charolais, and Red Angus cattle (351, 403, 464, and 492 $\mathrm{g} /$ animal/day, respectively). Both digestibility (\%) and digestible value (kg) increased and were affected by treatments. In detail, the CP digestibility was significantly higher for the $\mathrm{C2.0}$ (73.4\%) compared to $\mathrm{C1.5}$, C1.0, C0.5, and $\mathrm{CO}(68.6,65.7,61.2$, and 53.4\%, respectively), while C1.0 was similar to C0.5 and C1.5 treatments. Thus, the daily weight gain (g/animal/day) were $214,337,451,540$, and $595 \mathrm{~g}(\mathrm{P}<0.05)$ for $\mathrm{C0}$, $\mathrm{C} 0.5, \mathrm{C} 1.0, \mathrm{C} 1.5$, and $\mathrm{C2} .0$ treatments, respectively. The conclusion was that Brahman cattle had higher digestibility than Black Angus, Charolais, and Red Angus. In addition, the concentrate supplementation level from 1.0 to $1.5 \mathrm{~kg}$ per day in diets could be properly recommended for farmers' practice in terms of feed utilization.

Keywords: Beef, Breeding, Cattle, Crossbred, Digestibility, Supplementation.

Abbreviations: EG: elephant grass, RS: rice straw, Co.: concentrate feed, DM: dry matter, OM: organic matter, CP: crude protein, NDF: neutral detergent fiber, ME: metabolic energy; ADG: average daily gain, CLs: concentrate levels. C0, C0.5, C1.0, C1.5 and C2.0 corresponding to $0,0.5,1.0,1.5$ and $2.0 \mathrm{~kg}$ concentrate/animal/day.

\section{INTRODUCTION}

A total of Zebu crossbred cattle from Brahman, Ongole, Sindhi breeds were developed the most in An Giang province (Khang, 2004). The dry matter intakes of supplemental feed in diets of beef cattle at $6,12,18,24,30$, and 36 months of age are $0.29,0.63,0.94,1.41,2.11$, and $2.15 \mathrm{~kg} \mathrm{DM} /$ day (Truong and Thu, 2019). Thus, the amount of dry matter, crude protein, and metabolic energy consumed are lower than the nutrient requirements of Zebu cattle (Truong and Thu, 2019). The crossbred beef cattle is produced from the artificial insemination between Zebu cattle groups and the improved breeds such as Angus, Charolais, Wagyu, etc. (Vu et al., 2021).

These crossbred cattle have better beef performance compared to the local breeds, nevertheless, they require higher-quality diets, while in tropical developing countries high fiber diets are usually applied for beef cattle, due to the utilization of locally available low cost forages (Mwangi et al., 2019; Favero et al., 2019). Besides, the nutrient requirements of beef cattle depend on the age of cattle. After weaning, calves experience stress, then at 9-12 months of age they will recover (Hue, 2010).

Therefore, 13 months of age is a better period for the performance of cattle. The concentrate feeds play a crucial role in improving beef production by providing energy, protein, minerals, and other micro-nutrients. While previous studies on concentrate supplementation feed to improve nutrition and beef performance in An Giang province have been still limited. The hypothesis of this field trial is that beef cattle that are reared traditionally by the local people would not be suitable for high-produced beef cattle.

Thus, the goal of this study was carried out to evaluate the effects of breeds and different concentrate levels on the feed intake and rumen fermentation in beef cattle. 


\section{Material}

The field trial was carried out at Sau Duc cattle farm, which was located at Vinh Gia commune, Tri Ton district of An Giang province and the laboratory E205 of Department of Animal Science, College of Agriculture of Can Tho University during December 2018 till April 2019. The cattle breeds (at 13 months of age) were made by frozen sperm of specialized beef breeding such as Brahman, Black Angus, Charolais, and Red Angus with the local female breed (Zebu crossbred) by artificial insemination method.

\section{Experimental design}

A total of 20 crossbred beef cattle were arranged in a Group of Latin Square Designs $4 x(5 \times 5)$ with two factors. The first factor was beef cattle breeds (Brahman, Black Angus, Charolais, and Red Angus). The second factor was different levels of commercial concentrate (C) supplementation in the diet including $0,0.5,1.0,1.5$ and $2.0 \mathrm{~kg} / \mathrm{head} / \mathrm{day}$ corresponding to $\mathrm{C0}, \mathrm{C0.5}, \mathrm{C1} .0, \mathrm{C} 1.5$ and C2.0 treatments. In addition, Elephant grass (EG) was fed at a level of 5 $\mathrm{kg} / \mathrm{head} / \mathrm{day}$, while rice straw (RS) was fed ad libitum. Feeds used for feeding cattle, the elephant grass was planted in the cattle farm, rice straw was acquired from the rice fields of farmers around the farm. While commercial concentrate was occasionally acquired from the feed Company. The fixed quantities of concentrates were provided for the daily care of the animals 2 times at 7:00 am and 1:00 pm. Elephant grass was supplied at a level of $5 \mathrm{~kg} /$ animal/day (in the fresh matter) at 10 am and ad libitum rice straw. Clean and fresh water were offered ad libitum during the whole study. Before initiation of the study, all animals were given Ivermectin and Albendazole to cure for plausible external and internal parasites, respectively.

\section{Measurements taken}

Feeds and refusals were daily measured for analyses of dry matter (DM), organic matter (OM), crude protein (CP) and ash as following the procedure of AOAC (1990). The neutral detergent fiber (NDF) was measured according to Van Soest et al. (1991). The metabolic energy (ME) was determined according to Bruinenberg et al. (2002), in which ME $(\mathrm{MJ} / \mathrm{head} / \mathrm{day})=15.1 * \mathrm{DOM}$ (with DOM/DCP>7.0; DOM is digestible organic matter and DCP is digestible crude protein). Apparent DM, OM, CP and NDF digestibility were employed with the animal feces were daily collected and weighed according to McDonald et al. (2010). One experimental period was 2 weeks, including two weeks for dietary adaptation and another week for the sampling. Cattle were weighed for 2 consecutive days in the early morning before feedings at the end of each experimental period and the feed conversion ratio was calculated.

\section{Statistical analysis}

The data were analyzed by analysis of variance using the ANOVA of General Linear Model (GLM) of Minitab Reference Manual Release 16.0 (Minitab, 2010). Then, the paired comparison of two treatments, the Tukey test of the Minitab was used. The statistical equation for this model was $Y_{i j k l}=\mu+s_{i}+c_{j}+a_{k}+p_{l}+e_{i j k l}$; where: $Y_{i j k}$ : observation from cattle, $s_{i}$ : effect of Latin Square designs $(i=1,2,3,4), c_{j}$ : effect of concentrate supplement levels $(j=1,2,3,4,5)$, $a_{k}$ : the

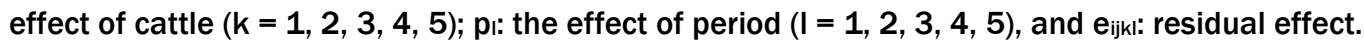

\section{RESULTS AND DISCUSSION}

\section{Chemical composition of feed}

The feed chemical compositions are shown in Table 1. The results revealed that the DM of rice straw was $88.4 \%$ higher than elephant grass (14.3\%) however; the CP content of elephant grass and rice straw was $8.39 \%$ and $5.45 \%$, respectively. Mo (2018) reported the lower amount of the NDF in elephant grass $(70.6 \%)$ in Kien Giang province, however, is comparable to Rusdy (2016) study which reported the following range; $63.9-75.4 \%$. The CP and NDF of rice straw in the present survey is comparable to the previous study by Don et al. (2020) which reported a range of 2.0-6.0\% and 66.3$73.2 \%$, respectively. The DM and CP values of concentrate were $89.0 \%$ and $15.6 \%$, respectively. The results are similar to previous findings of Huyen et al. (2017) in the Son La province (88.9\% and $15.4 \%$, respectively). Concisely, in this study, the concentrate is a major contributor of protein and metabolic energy to crossbred beef cattle, while elephant grass and rice straw are a basic feed.

\section{Table 1 - Chemical composition (\%DM) of diet ingredients used in the field trial}

\begin{tabular}{lccccc} 
Feeds & DM \% & \multicolumn{3}{c}{ DM \% } \\
\cline { 3 - 6 } & & OM & CP & NDF & Ash \\
\hline Elephant grass & 14.3 & 90.2 & 8.39 & 67.9 & 9.80 \\
Rice straw & 88.4 & 89.5 & 5.45 & 71.1 & 10.5 \\
Concentrate & 89.0 & 91.2 & 15.6 & 35.7 & 8.79 \\
DM: dry matter, OM: organic matter, CP: crude protein, NDF: neutral detergent fiber & & &
\end{tabular}


Feed, nutrient, and metabolic energy (ME) intakes of experimental beef cattle

In this survey, elephant grass intakes were similar in all treatment groups, conversely, intake of concentrate and rice straw were significant among treatment groups $(P<0.05)$. The DM of rice straw intakes decreased by increasing concentrate supplement levels in the experimental cattle diets. The rice straw intakes of Brahman cattle was lower than Black Angus, Charolais, and Red Angus (2.12, 3.58, 3.66 and $3.57 \mathrm{~kg}$, respectively). Brahman's DM, OM, CP, NDF, and ME intake were significantly lower than crossbred cattle. The feed intake and total nutrients consumed by cattle in the field trial are presented in Table 2.

The results indicate that the DM intake of Brahman cattle $(3.72 \mathrm{~kg} /$ animal/day) were lower than Black Angus, Charolais and Red Angus (5.18, 5.26 and $5.17 \mathrm{~kg} /$ animal/day, respectively) (Table 2). According to Kearl (1982), the nutrient requirement of crossbred beef cattle is $5.35-6.00 \mathrm{kgDM} /$ animal/day for 0.25-0.75 kg daily weight gain. However, Dung et al. (2016) suggest that feed intake of beef cattle in Vietnam was lower than the result of Kearl (1982) ranged 6$8 \%$. The DM consumption was significantly different among treatment groups $(P<0.05)$. It was $4.00,4.53,4.86,5.28$ and $5.49 \mathrm{~kg} /$ animal/day corresponding to C0, C0.5, C1.0, C1.5 and C2.0 treatments. Dry matter content in the present study was found to be comparable to the results of Quang et al. (2015) which reported that the total feed intake increased as the quantity of concentrate consumed increased in Brahman cattle. Besides, this may also increase the DM intake as reported by Pilajun et al. (2016) in Thai native $x$ Lowline Angus crossbred beef cattle.

The daily CP intake of Brahman cattle $(0.318 \mathrm{~kg})$ were significantly different with Black Angus $(0.396 \mathrm{~kg})$, Charolais $(0.401 \mathrm{~kg})$, and Red Angus cattle $(0.396 \mathrm{~kg})(\mathrm{P}<0.05)$. While there were not found any differences in $\mathrm{CP}$ consumption in crossbred cattle breeds during the present study $(P<0.05)$. The $C P$ intake of crossbred cattle in this field trial was similar to the results of Kearl (1982) which reported $0.282-0.571 \mathrm{~kg}$ for $0-0.75 \mathrm{~kg}$ daily weight gain. The CP intake of C2.0 treatment was higher than C1.5, C1.0, C0.5 and C0 treatments $(0.504$ vs $0.447,0.379,0.316$ and $0.242 \mathrm{~kg}$, respectively). Because of the protein concentration supplement in the diets, these findings were consistent with the results of Hai and Van (2016), they reported, Brahman cattle with CP intake increased by increasing concentrate in diets.

In the present study, the NDF intake by crossbred cattle breeds was not significantly different $(P>0.05)$, on the other hand, was higher than Brahman cattle $(P<0.05)$. It was 3.32, 3.38, 3.33, and $2.28 \mathrm{~kg} /$ animal/day for Red Angus, Charolais, Black Angus, and Brahman cattle. It was affected by DM intake in the experimental lowest for Brahman cattle. The NDF intake $(\mathrm{kg} /$ animal/day) was significantly different $(P<0.05)$ among treatments. It did not reduced $(P<0.05)$ for C0, C0.5, C1.0, C1.5 and C2.0 treatments (2.80, 3.02, 3.10, 3.24 and 3.23, respectively).

The ME consumption (MJ/animal/day) of Brahman cattle was 34.4 MJ $(\mathrm{P}<0.05)$ lower than Black Angus, Charolais, and Red Angus cattle (42.2, 42.1, and 42.5 MJ, respectively). However, the ME intakes of crossbred cattle breeds was not significant $(P>0.05)$. The ME intakes was significantly different $(P<0.05)$ among the treatments and gradually increased for C0, C0.5, C1.0, C1.5 and C2.0 treatments corresponding to 30.7, 36.0, 41.0, 44.7 and 49.1 MJ/animal/day. Mo (2018) reported that $\mathrm{CP}$ and ME intake were improved by increasing concentrate supplementation. In this field trial, the ME intake in Table 2 is gradually enhanced by increasing concentrate supplementation from 0 to $2 \mathrm{~kg}$ in the diets. The C2.0 treatment consumed more ME than the result of Kearl (1982) which reported $46.5 \mathrm{MJ} / 0.5 \mathrm{~kg}$ daily weight gain.

Briefly, the data showed that the total nutrient intake of Black Angus, Charolais and Red Angus was higher than Brahman. Moreover, the increasing concentrate supplements levels causes a better nutrient intake of beef cattle (Table 3).

\section{Table 2 - Total nutrient intake of cattle crossbred by different treatments}

\begin{tabular}{|c|c|c|c|c|c|c|c|c|c|}
\hline \multirow{2}{*}{ Parameters } & & \multicolumn{3}{|c|}{ Feed intake, kgDM } & \multicolumn{5}{|c|}{ Nutrient intake, kg/animal/day } \\
\hline & & EG & RS & Co. & DM & OM & CP & NDF & ME \\
\hline \multirow{4}{*}{ Breeds } & Brahman & 0.71 & $2.12^{b}$ & 0.890 & $3.72^{b}$ & $3.35^{b}$ & $0.318^{b}$ & $2.28^{b}$ & $34.4^{b}$ \\
\hline & Black Angus & 0.71 & $3.58^{a}$ & 0.890 & $5.18^{a}$ & $4.66^{a}$ & $0.396^{a}$ & $3.33^{a}$ & $42.2^{a}$ \\
\hline & Charolais & 0.71 & $3.66^{a}$ & 0.890 & $5.26^{a}$ & $4.73^{a}$ & $0.401^{a}$ & $3.38^{a}$ & $42.1^{a}$ \\
\hline & Red Angus & 0.71 & $3.57^{a}$ & 0.890 & $5.17^{a}$ & $4.65^{a}$ & $0.396^{a}$ & $3.32^{a}$ & $42.5^{a}$ \\
\hline \multirow{5}{*}{$\begin{array}{l}\text { Concentrate } \\
\text { Levels }\end{array}$} & $\mathrm{CO}$ & 0.71 & $3.29^{a b}$ & - & $4.00^{c}$ & $3.58^{d}$ & $0.242^{\mathrm{e}}$ & $2.80^{b}$ & $30.7^{\mathrm{e}}$ \\
\hline & co.5 & 0.71 & $3.37^{a}$ & 0.445 & $4.53^{b}$ & $4.07^{c}$ & $0.316^{d}$ & $3.02^{\mathrm{ab}}$ & $36.0^{d}$ \\
\hline & C1.0 & 0.71 & $3.26^{\mathrm{ab}}$ & 0.890 & $4.86^{b}$ & $4.37^{b}$ & $0.379^{c}$ & $3.10^{a}$ & $41.0^{c}$ \\
\hline & C1.5 & 0.71 & $3.23^{a b}$ & 1.336 & $5.28^{a}$ & $4.75^{a}$ & $0.447^{b}$ & $3.24^{a}$ & $44.7^{b}$ \\
\hline & C2.0 & 0.71 & $3.00^{\mathrm{b}}$ & 1.781 & $5.49 a$ & $4.95^{\mathrm{a}}$ & $0.504^{a}$ & $3.23^{a}$ & $49.1^{\mathrm{a}}$ \\
\hline \multirow{2}{*}{$\mathbf{P}$} & Breeds & - & 0.0001 & - & 0.0001 & 0.0001 & 0.0001 & 0.0001 & 0.0001 \\
\hline & CLs & - & 0.042 & - & 0.0001 & 0.0001 & 0.0001 & 0.0001 & 0.0001 \\
\hline \multirow{2}{*}{ SE } & Breeds & - & 0.077 & - & 0.077 & 0.069 & 0.004 & 0.055 & 0.695 \\
\hline & CLs & - & 0.086 & - & 0.086 & 0.077 & 0.005 & 0.061 & 0.777 \\
\hline
\end{tabular}


Table 3 - Nutrient per DM consumption and nutrients intake per $100 \mathrm{~kg}$ body weight

\begin{tabular}{|c|c|c|c|c|c|c|c|c|}
\hline \multirow{2}{*}{ Parameters } & & \multicolumn{3}{|c|}{ Nutrient consumption ratio, \%DM } & \multicolumn{4}{|c|}{ Nutrients intake/100kgBW, kgDM } \\
\hline & & Co. & CP & NDF & DM & OM & $\mathbf{C P}$ & NDF \\
\hline \multirow{4}{*}{ Breeds } & Brahman & $22.2^{a}$ & $8.40^{a}$ & $61.9^{b}$ & $2.15^{b}$ & $1.94^{b}$ & $0.185^{a}$ & $1.32^{c}$ \\
\hline & Black Angus & $16.1^{b}$ & $7.55^{b}$ & $64.6^{a}$ & $2.18^{b}$ & $1.96^{b}$ & $0.167^{b}$ & $1.40^{\mathrm{bc}}$ \\
\hline & Charolais & $16.1^{b}$ & $7.55^{b}$ & $64.6^{a}$ & $2.37^{a}$ & $2.13^{a}$ & $0.181^{a}$ & $1.52^{a}$ \\
\hline & Red Angus & $16.2^{b}$ & $7.55^{b}$ & $64.6^{a}$ & $2.25^{\mathrm{ab}}$ & $2.02^{\mathrm{ab}}$ & $0.172^{\mathrm{ab}}$ & $1.44^{\mathrm{ab}}$ \\
\hline \multirow{5}{*}{$\begin{array}{l}\text { Concentrate } \\
\text { Levels }\end{array}$} & $\mathrm{CO}$ & $0.0 \mathrm{e}$ & $6.08^{e}$ & $70.0^{a}$ & $1.83^{d}$ & $1.64^{d}$ & $0.111^{\mathrm{e}}$ & $1.28^{b}$ \\
\hline & $\mathrm{Co.5}$ & $10.2^{\mathrm{d}}$ & $7.04^{d}$ & $66.5^{b}$ & $2.09^{c}$ & $1.88^{c}$ & $0.147^{d}$ & $1.39^{a}$ \\
\hline & C1.0 & $18.8^{c}$ & $7.86^{c}$ & $63.5^{c}$ & $2.29^{b}$ & $2.06^{b}$ & $0.180^{c}$ & $1.45^{a}$ \\
\hline & C1.5 & $26.1^{b}$ & $8.57^{b}$ & $61.0^{d}$ & $2.44^{\mathrm{ab}}$ & $2.20^{\mathrm{ab}}$ & $0.209^{b}$ & $1.49^{a}$ \\
\hline & C2.0 & $33.1^{\mathrm{a}}$ & $9.26^{a}$ & $58.5^{e}$ & $2.55^{a}$ & $2.30^{a}$ & $0.236^{a}$ & $1.49^{a}$ \\
\hline \multirow{2}{*}{$\mathbf{P}$} & Breeds & 0.0001 & 0.0001 & 0.0001 & 0.001 & 0.001 & 0.002 & 0.0001 \\
\hline & CLs & 0.0001 & 0.0001 & 0.0001 & 0.0001 & 0.0001 & 0.0001 & 0.0001 \\
\hline \multirow{2}{*}{ SE } & Breeds & 0.493 & 0.053 & 0.184 & 0.038 & 0.034 & 0.003 & 0.024 \\
\hline & CLs & 0.551 & 0.060 & 0.206 & 0.042 & 0.038 & 0.004 & 0.027 \\
\hline
\end{tabular}

Nutrients intake ratio and nutrients intake per $100 \mathrm{~kg}$ body weight

Table 3 is shown the nutrients intake ratio and nutrients intake/100 kg body weight. Under the conditions of this study, the proportion of concentrate per DM intake on Brahman $(22.3 \%)$ is significantly higher $(P<0.05)$ than Black Angus (16.1\%), Charolais (16.1\%), and Red Angus (16.2\%). Because the DM intakes of Brahman cattle is significantly lower than crossbred cattle breeds (Table 2). However, the DM intakes of crossbred cattle breeds were not significantly different ( $P>0.05)$. In a previous study, Truong and Thu (2019) concluded that concentrate supplementation for beef cattle (Zebu crossbred) with the optimum economic return was $15.6-16.1 \%$ of the diet practiced by cattle keepers. The Co./DM ratio

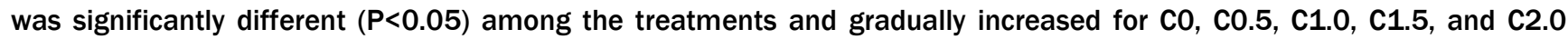
treatments corresponding to the growth rate of $0,10.2,18.8,26.1$, and $33.1 \%$. The results of the study are in accordance with the previous studies reported by Hai and Van (2016), Quang et al. (2015), and Pilajun et al. (2016). The proportion of CP/DM on crossbred cattle breeds $(7.55 \%)$ was not significantly different $(P>0.05)$, while the Brahman cattle $(8.40 \%)$ was the highest $(P<0.05)$ in the field trial. The $C P$ in the diet ratio was significantly different $(P<0.05)$ among treatments, the highest value for $\mathrm{C} 2.0$ (9.26\%) and lowest value for C0 (6.08\%). In a diet adaptation study, Lazzarini et al. (2009) reported that the $7 \%$ CP in the diet from low-quality forages are necessary for the diet to sustain microbial growth and support efficient fibrous carbohydrate digestion.

Both Brahman and Black Angus cattle breeds had less DM intake per $100 \mathrm{~kg}$ live weight than Charolais $(2.15,2.18$ and $2.37 \mathrm{kgDM}$, respectively), while Red Angus (2.25 kgDM) was not significantly different from crossbred groups $(P>0.05)$. These results are higher than the report of Ornaghi et al. (2017) in $1 / 2$ Brown Swiss - 1/2Nellore cattle being 2.07$2.23 \mathrm{~kg} / 100 \mathrm{kgBW}$ and Valero et al. (2015) being 1.87-2.07 kg/100 kgBW but this is similar to Hai and Van (2016) being 1.75-2.57 kg/100kg BW in Brahman cattle. The DM intakes per $100 \mathrm{~kg}$ body weight of experimental cattle was significantly different among treatments $(P>0.05)$. It was $2.44 \mathrm{~kg} / 100 \mathrm{kgBW}$ for $\mathrm{C} 1.5$ treatment compared to 2.09 and $2.55 \mathrm{~kg}$ for C1.0 and C2.0 treatments, respectively. While C1.5 treatment was higher than $(P<0.05)$ C0.5 and CO $(2.09$ and $1.83 \mathrm{~kg}$, respectively). In previous study, Granja-Salcedo (2016) reported that, increasing concentration value in the diets causes an increased DM intakes per $100 \mathrm{~kg}$ live weight.

The CP intake/100kgBW of cattle at $\mathrm{C2} .0$ treatment was significantly higher $(\mathrm{P}<0.05)$ than $\mathrm{C1.5,} \mathrm{C1.0,} \mathrm{C0.5}$ and $\mathrm{CO}$ treatments $(0.236,0.209,0.180,0.147$ and $0.111 \mathrm{~kg} / 100 \mathrm{kgBW}$, respectively). The $\mathrm{C} 2.0$ treatment was similar to the results of Thu and Dong (2015) on Sind crossbred cattle being $230 \mathrm{~g} / 100 \mathrm{kgBW}$. Although, the proportion of CP in the diet was not significantly different $(P>0.05)$ in crossbred cattle breeds. Opposite, $C P$ intake per $100 \mathrm{~kg}$ body weight was significantly different $(P<0.05)$, with the highest value for Charolais cattle $(0.181 \mathrm{~kg})$ and the lowest value for Black Angus cattle $(0.167 \mathrm{~kg})$. Therefore, a new hypothesis in the current field trial is that the proportion of CP/DM intake is less exactly than $\mathrm{CP}$ consumption on $100 \mathrm{~kg}$ body weight. The above results explained that increasing accuracy from $\mathrm{CP}$ intake in the diet could reduce standard error, whereas the various ratios between supplements feed and forage on diet were the main cause. Because the CP was intermediate for genotype expression and muscle formation for the breed, it is necessary to respond to enough protein in the diet to improve growth performance (Peng et al., 2018).

The mentioned results explain that the CP/DM intake ratio was affected by fiber carbohydrates of low-quality forages. However, a study of CP per body weight could be better than the proportion CP in diets in cattle. 


\section{Nutrients digestibility and digestible nutrients of experimental cattle}

The nutrients digestibility and digestible nutrients of experimental crossbred beef cattle are shown in Table 4. Statistical analysis of data showed that the nutrient digestibility (\%) of Black Angus, Charolais and Red Angus cattle were significantly lower than Brahman cattle $(\mathrm{P}<0.05)$. While the nutrient digestible value $(\mathrm{kg} /$ animal/day) were highest among Brahman cattle. The differences in nutrients digestibility between the two cattle groups in the experiment might be due to both the breeds differences and the composition of rumen microorganisms. Therefore, local cattle breeding would be important for the new reproduction cattle program (Table 4).

The DM digestibility of C1.0 treatment (56.5\%) was higher than both $\mathrm{C0.5}(52.7 \%)$ and CO $(52.3 \%)$ treatments $(P<0.05)$. However, It was not significantly different with $\mathrm{C} 1.5$ and $\mathrm{C} 2.0$ (57.3 and 60.0\%, respectively) $(\mathrm{P}>0.05)$. The result of C1.0 treatment is similar to the findings of Hai and Van (2016) which reported supplemented with $27 \%$ concentrate in beef cattle diet is $58.8 \%$. Besides, it was lower than the values being $62.6-67.2 \%$ reported by Valero et al. (2015) in the crossbred cattle supplemented with $50 \%$ concentrate in the diet. The CP digestibility (\%) was significantly different among the treatments $(P<0.05)$. It was $54.3,61.2,65.7,68.6$, and $73.4 \%$ corresponding to $\mathrm{C0}, \mathrm{C} 0.5, \mathrm{C} 1.0, \mathrm{C1.5}$ and C2.0 treatments. The apparent digestibility of CP was low among groups with diet of high rice straw. Because the structure of carbohydrates in rice straw was higher than concentrated supplements and non-fiber carbohydrates affected the digestibility of beef cattle. This finding was consistent with the results reported by Quang et al. (2015) and Hai and Van (2016).

The DM digestible value $(\mathrm{kg} /$ animal/day) was significantly increased with increasing concentrate supplement level $(p<0.05)$, the highest value for $\mathrm{C} 2.0(3.27 \mathrm{~kg})$ and the lowest value for $\mathrm{CO}(2.07 \mathrm{~kg})$. Likewise, the digestible of OM value (kg/animal/day) was highest for C2.0 (3.09 kg) compared to C1.5 (2.81 kg), C1.0 (2.58 kg), C0.5 (2.26 kg) and C0 treatments $(1.93 \mathrm{~kg})$. The digestible $\mathrm{CP}$ value $(\mathrm{kg} /$ animal/day) was proportionally increased by increasing levels of concentrate in the diets $(\mathrm{P}<0.05)$ It was $0.129,0.194,0.248,0.305$ and $0.369 \mathrm{~kg}$ for C0, C0.5, C1.0, C1.5 and C2.0 treatments, respectively. According to Kearl (1982), the digestible requirements of crossbred cattle was $0.377 \mathrm{kgCP} / 0.5$ $\mathrm{kg}$ daily weight gain. While protein is needed to meet for cell repair and synthetic processes in the body. The transformation of feed protein into body protein is an important process of nutrition and metabolism (Dong and Thu, 2020).

Based on rumen fermentation characteristics, the Brahman cattle had more nutrients digestibility than Black Angus, Charolais, and Red Angus cattle. The digestibility of treatments was increased by increasing concentrate supplement levels in the diets.

\section{Table 4 - Nutrient digestibility and digestible nutrient of experimental beef cattle}

\begin{tabular}{|c|c|c|c|c|c|c|c|c|c|}
\hline \multirow{2}{*}{ Parameters } & & \multicolumn{4}{|c|}{ Apparent digestibility, \% } & \multicolumn{4}{|c|}{ Digestible nutrients, kg } \\
\hline & & DM & OM & $\mathrm{CP}$ & NDF & DM & OM & $\mathbf{C P}$ & NDF \\
\hline \multirow{4}{*}{ Breeds } & Brahman & $62.0^{a}$ & $64.1^{\mathrm{a}}$ & $66.9^{a}$ & $66.9^{a}$ & $2.32^{b}$ & $2.16^{b}$ & $0.220^{c}$ & $1.53^{c}$ \\
\hline & Black Angus & $53.1^{b}$ & $56.7^{b}$ & $61.9^{a}$ & $57.1^{c}$ & $2.77^{a}$ & $2.65^{a}$ & $0.251^{b}$ & $1.90^{\mathrm{b}}$ \\
\hline & Charolais & $53.3^{b}$ & $55.9^{b}$ & $65.7^{\mathrm{ab}}$ & $59.6^{\mathrm{ab}}$ & $2.81^{a}$ & $2.65^{a}$ & $0.269^{a}$ & $2.01^{\mathrm{ab}}$ \\
\hline & Red Angus & $54.7^{b}$ & $57.1^{b}$ & $63.2^{b}$ & $61.5^{b}$ & $2.84^{a}$ & $2.67^{a}$ & $0.256^{\mathrm{ab}}$ & $2.04^{a}$ \\
\hline \multirow{5}{*}{$\begin{array}{l}\text { Concentrate } \\
\text { Levels }\end{array}$} & $\mathrm{CO}$ & $52.3^{b}$ & $54.3^{c}$ & $53.4^{d}$ & $63.0^{a}$ & $2.07^{e}$ & $1.93^{e}$ & $0.129 \mathrm{e}$ & $1.75^{c}$ \\
\hline & Co.5 & $52.7^{b}$ & $55.9^{c}$ & $61.2^{a}$ & $59.1^{b}$ & $2.38^{d}$ & $2.26^{d}$ & $0.194^{d}$ & $1.78^{\mathrm{bc}}$ \\
\hline & C1.0 & $56.5^{\mathrm{a}}$ & $59.3^{b}$ & $65.7^{\mathrm{bc}}$ & $61.4^{b}$ & $2.73^{c}$ & $2.58^{c}$ & $0.248^{c}$ & $1.90^{\mathrm{abc}}$ \\
\hline & C1.5 & $57.3^{a}$ & $59.9 \mathrm{ab}$ & $68.6^{b}$ & $60.7^{\mathrm{ab}}$ & $2.98^{b}$ & $2.81^{b}$ & $0.305^{b}$ & $1.94^{\mathrm{ab}}$ \\
\hline & C2.0 & $60.0^{a}$ & $62.8^{a}$ & $73.4^{a}$ & $62.1^{\mathrm{ab}}$ & $3.27^{a}$ & $3.09 a$ & $0.369^{a}$ & $1.99 a$ \\
\hline \multirow{2}{*}{$\mathbf{P}$} & Breeds & 0.0001 & 0.0001 & 0.004 & 0.0001 & 0.0001 & 0.0001 & 0.0001 & 0.0001 \\
\hline & CLs & 0.0001 & 0.0001 & 0.0001 & 0.014 & 0.0001 & 0.0001 & 0.0001 & 0.0001 \\
\hline \multirow{2}{*}{ SE } & Breeds & 0.784 & 0.729 & 1.031 & 0.730 & 0.049 & 0.044 & 0.004 & 0.037 \\
\hline & CLs & 0.876 & 0.815 & 1.153 & 0.817 & 0.055 & 0.049 & 0.004 & 0.042 \\
\hline
\end{tabular}

DM: dry matter, OM: organic matter, CP: crude protein, NDF: neutral detergent fiber and BW: body weight. CLs: concentrate levels. C0, C0.5, C1.0, C1.5 and C2.0 corresponding to $0,0.5,1.0,1.5$ and $2.0 \mathrm{~kg}$ concentrate/animal/day.

\section{Daily weight gain}

The initial body weight of beef cattle was not significantly different $(P>0.05)$ among treatments, the lowest value for C1.5 (244 kg) and the highest value for C0 $9217 \mathrm{~kg})$. Then, the final body weight was 220, 222, 221, 221, and 224 kg ( $P>0.05$ ) corresponding to C0, C0.5, C1.0, C1.5, and C2.0 treatments. In our study, the daily weight gain (g/animal/day) of Brahman cattle (351 g) was lower than ( $\mathrm{P}<0.05)$ Black Angus (403 g), Charolais (464 g), and Red Angus (492 g). However, increased average weight gain was affected by increasing concentrate supplement levels on diets. It was 214 , 337, 451, 540 and $595 \mathrm{~g} /$ animal/day corresponding to C0, C0.5, C1.0, C1.5 and C2.0 treatments. While C1.5 treatment was not significantly different $(P>0.05)$ compared to C1.0 and C2.0 treatments. Mean values for daily weight gain for breeds and different concentration levels are presented in Figure 1. 
Previous studies, both Quang et al. (2015) and Pilajun et al. (2016) reported that increasing the concentration supplements in the diets of beef cattle improved the performance. The result of the field trial was similar to the findings of Kongphitee et al. (2018), which reported that the daily weight gain of beef cattle was increased from $391 \mathrm{~g} / \mathrm{day}$ to 569 $\mathrm{g} /$ day by increasing ME intake from 40.2 to $51.9 \mathrm{MJ} /$ day. In another study, Vu et al. (2017) found that the daily weight gain of Red Angus x Brahman crossbred at 12-18 months of age was $498 \mathrm{~g} /$ day.

In present study, the dry matter intake of Brahman cattle was lower than high produce crossbred beef cattle. However, the Brahman cattle had more digestibility than Black Angus, Charolais and Red Angus cattle. Because, these crossbred cattle have better beef performance compared to the local cattle breed and they require better quality diets. The commercial concentrate supplementation levels in the diets affected nutrients consumption and nutrients digestibility in crossbred cattle in An Giang. In detail, daily CP and ME intake increased from CO to C2.0 and were significantly different among the treatments $(P<0.05)$. The digestibility and nutrients digestible value were highest for C2.0 treatment and lowest for C0 treatment $(P<0.05)$. However, no difference was found between $\mathrm{C} 1.0$ and $\mathrm{C} 1.5$ treatments for nutrients digestibility. To our knowledge, the present study has a new hypothesis, which needs to discuss for the next studies. This is accuracy for CP consumption of cattle among the proportion of CP/DM in diet or CP/BW in other experimental analyses. Eventually, the local cattle are important in beef cattle genomic breeding programs.

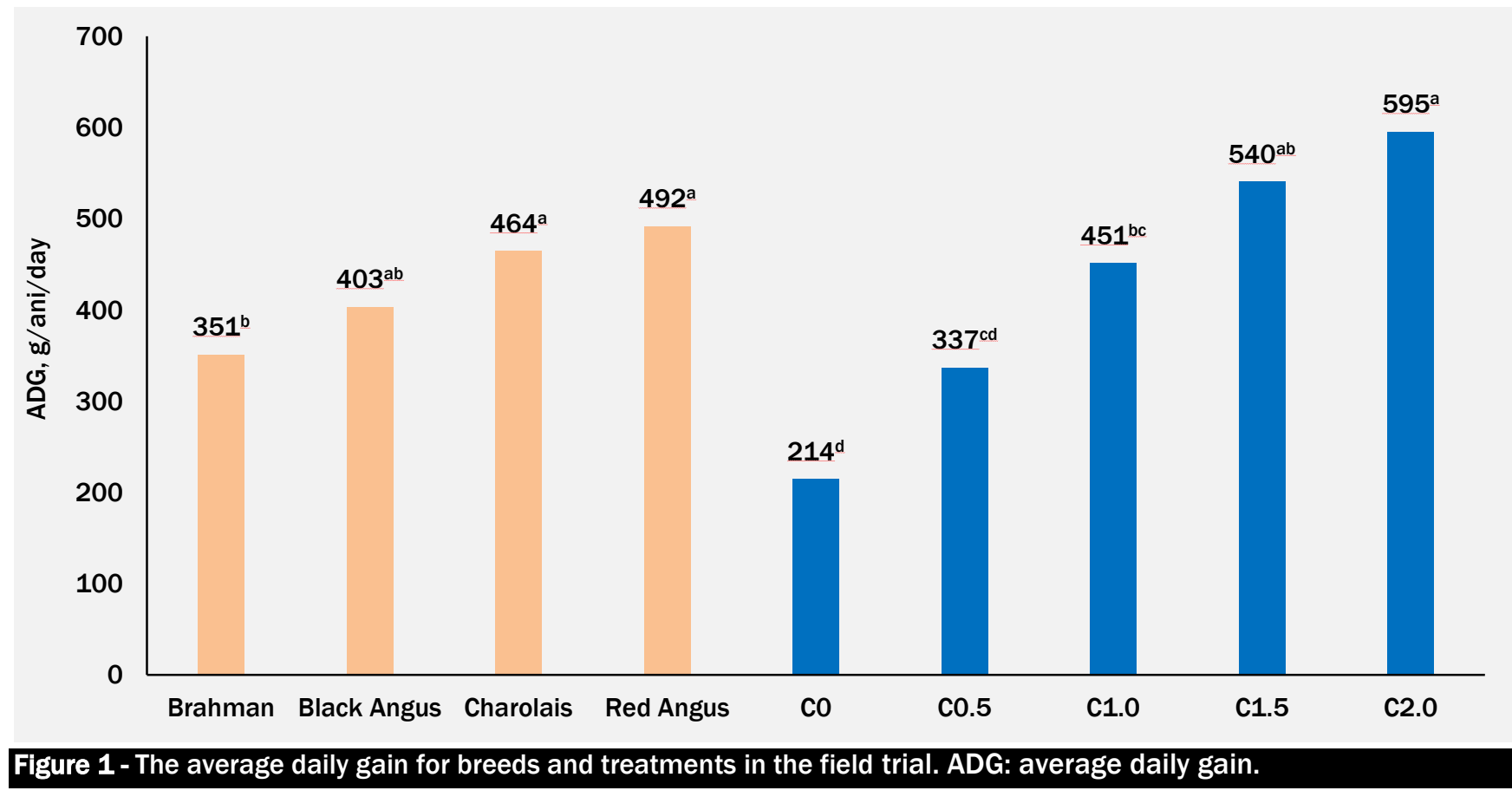

\section{CONCLUSION}

The nutrient requirement and daily weight gain of Black Angus, Charolais, and Red Angus were higher than Brahman cattle. However, the digestibility of Brahman cattle was higher than high-product crossbred beef cattle. The concentrate supplement was at 1.0-1.5 kg/animal/day and gave the optimal results in this field trial. This result can be used in crossbred cattle farming and a also there is a need to study on the optimum nutrients level in a different age of cattle.

\section{DECLARARATIONS}

\section{Corresponding author}

Nguyen Binh Truong; Department of Animal and Veterinary Sciences, Faculty of Agriculture and Natural Resources, An Giang University, Vietnam. Email: nbtruong@agu.edu.vn ; ORCID: https://orcid.org/0000-0003-2056-3479

\section{Author contribution}

N.B.Truong conceived and designed the field trial; analyzed the data; and wrote the paper.

\section{Competing interest}

The author declared no conflict of interest.

\section{Acknowledgements}

This research is conducted at a private SD cattle farm. The Author also thanks the Department of Animal Sciences of the College of Agriculture, Can Tho University for facilitating the equipment and laboratory staff of the field trial. 


\section{REFERENCES}

AOAC (1990). Official methods of analysis (15 th edition). Washington. DC. Volume 1: 69-90.

Bruinenberg $\mathrm{MH}$, Valk H, Korevaar $\mathrm{H}$ and Struik PC (2002). Factors affecting digestibility of temperate forages from semi-natural grasslands. Grass and Forage Science, 57 (3): 292-301. DOI: https://doi.org/10.1046/j.1365-2494.2002.00327.x

Don VN, Cuong VC and Toan NV (2020). The Current Utilisation and Possible Treatments of Rice Straw as Ruminant Feed in Vietnam: A Review. Pakistan Journal of Nutrition, 19 (3): 91-104. DOI: https://dx.doi.org/10.3923/pjn.2020.91.104

Dong NTK and Thu NV (2020). Effects of dietary protein sources on feed and nutrient intake, digestibility and rumen parameters of growing Bach Thao goats. Journal of Animal Science and Technology, 108 (February, 2020): 43-49. Link: https://vcn.org.vn/xuat-ban/tap-chi-khoa-hoc-cong-nghe-chan-nuoi-so-108-thang-02-2020-journal-of-animal-science-andtechnology-vol-108-february-2020

Dung VT, Ngoan LD and Cuong VC (2016). A comparison of actual nutrient intakes with the nutrient requirements developed by Kearl (1982) in growing beef cattle kept in Eakar district conditions. Journal of Animal Science and Technology. 61 (3, 2016):77-85

Favero R, Menezes GDO, Torres RAA, Silva LOC, Bonin MN, Feijó GLD, and Gomes RD C (2019). Crossbreeding applied to systems of beef cattle production to improve performance traits and carcass quality. Animal. 13(11): 2679-2686. D0I: https://doi.org/10.1017/s1751731119000855

Granja-Salcedo YT, Ribeiro Júnior CS, de Jesus RB, Gomez-Insuasti AS, Rivera AR, Messana JD and Berchielli TT (2016). Effect of different levels of concentrate on ruminal microorganisms and rumen fermentation in Nellore steers. Archives of Animal Nutrition. 70(1): 17-32. DOI: https://doi.org/10.1080/1745039x.2015.1117562

Hai DV and Van NT (2016). Effects of forage: Concentrate ratio on feed intake, nutrient digestibility, growth performance and methane emission of crossbred Brahman cattle. Journal of Animal Science and Technology. 64: 64-70.

Hue PT (2010). Performance and meat production of Lai Sind, F1 (Brahman $x$ Lai Sind) and $F_{1}$ (Charolais $x$ Lai Sind) cattle in Dak Lak. PhD thesis specialized in Agriculture, Faculty of Agriculture \& Applied Biology, Hanoi University of Agriculture, Hanoi. Link: https://tailieumienphi.vn/doc/luan-an-tien-si-nong-nghiep-kha-nang-sinh-truong-san-xuat-thit-cua-bo-lai-sind-f-2tb8ta.html

Huyen LTT, Ha LV and Dang PK (2017). The impact of supplementing treated rice straw for fattening beef cattle in Son La province. Journal of Animal Husbandry Sciences and Technics. 218:48-52

Kearl LC (1982) Nutrient requirements of ruminants in development countries, International feedstuffs institute Utah Agricultural experiment station. Utah State University. Loga, Utah, USA. Google Scholar ; CAB Direct

Khang DN (2004). Cassava foliage as a protein source for cattle in Vietnam Acta Universitatis Agriculturae Sueciae. Agraria, Uppsala Vol. 471. Pp. 1401-6249. ISBN 91-576-6752-7. Link: https://pub.epsilon.slu.se/640/1/Agraria471.pdf

Kongphitee K, Sommart K, Phonbumrung T, Gunha T and Suzuki T (2018). Feed intake, digestibility and energy partitioning in beef cattle fed diets with cassava pulp instead of rice straw. Asian-Australas Journal of Animal Science. 31(9): 1431-1441. DOI: https://doi.org/10.5713/ajas.17.0759

Lazzarini I, Detmann E, Sampaio CB, Paulino MF, Valadares Filho SDC, Souza MAD and Oliveira FA (2009). Intake and digestibility in cattle fed low-quality tropical forage and supplemented with nitrogenous compounds. Revista Brasileira de Zootecnia. 38(10): 2021-2030. DOI: https://doi.org/10.1590/S1516-35982009001000024

McDonald P, Edwards RA, Greenhalgh JFD, Morgan CA, Sinclair LA and Wilkinson RG, (2010). Animal Nutrition (7th edition) Longman Scientific and Technical. N.Y. USA.

Minitab, (2010). Minitab Reference Manual. Release 16 for Windows, Minitab Inc, USA

Mo D (2018). Effects of the concentrate level on performance and methane emission (Red Sindhi $x$ VietNam) crossbred cattle in the MeKong Delta. Journal of Animal Husbandry Sciences and Technics. 235: 54-59

Mwangi FW, Charmley E, Gardiner CP, Malau-Aduli BS, Kinobe RT, and Malau-Aduli A (2019). Diet and Genetics Influence Beef Cattle Performance and Meat Quality Characteristics. Foods. 8(12): 648. DOI: https://doi.org/10.3390/foods8120648

Ornaghi MG, Passetti RAC, Torrecilhas JA, Mottin C, Vital ACP, Guerrero A, Sañudo C, Campo MDM and Prado IN (2017). Essential oils in the diet of young bulls: Effect on animal performance, digestibility, temperament, feeding behaviour and carcass characteristics. Animal Feed Science and Technology. 234:274-283. DOI: https://doi.org/10.1016/j.anifeedsci.2017.10.008

Peng HQ, Khan AN, Xue B, Yan HT and Wang SZ (2018). Effect of different levels of protein concentrates supplementation on the growth performance, plasma amino acids profile and mTOR cascade genes expression in early-weaned yak calves sianAustralasian Journal of Animal Sciences. 31(2): 218-224. DOI: https://doi.org/10.5713/ajas.16.0999

Pilajun R, Thummasaeng $K$ and Wanapat $M$ (2016). Nutrient digestibility and rumen fermentation of Thai native purebred compared with Thai native $x$ Lowline Angus crossbred beef cattle. Journal of Applied Animal Research, 44(1):355-358. DOI: https://doi.org/10.1080/09712119.2015.1079526

Quang DV, Ba NX, Doyle PT, Hai DV, Lane PA, Malau-Aduli AEO, Van NH and Parsons D, (2015). Effect of concentrate supplementation on nutrient digestibility and growth of Brahman crossbred cattle fed a basal diet of grass and rice straw. Journal of Animal Science and Technology, 57: Article No. 35 (2015). DOI: https://doi.org/10.1186/s40781-015-0068-y

Rusdy M (2016). Elephant grass as forage for ruminant animals. Livestock Research for Rural Development, 28 : Article \#49 . Link: http://Irrd.cipav.org.co/Irrd28/4/rusd28049.html

Thu NV and Dong NTK (2015). Effect of dietary crude protein levels supplemented by multi-nutrient cakes on feed intake, rumen parameters and nitrogen retention of Lai Sind cattle. Journal of Science Can Tho University. 37 (2015)(1): 11-17. Link: https://sj.ctu.edu.vn/ql/docgia/tacgia-1137/baibao-8121/doi-ctu.jvn.2015.077.htm 
Truong NB and Thu NV (2019). A survey of dietary neutral detergent fiber levels in the ration of beef cattle in An Giang Province. Journal of Animal Science and Technology, 101: 57-67. Link: https://ven.org.vn/xuat-ban/tap-chi-khoa-hoc-cong-nghe-channuoi-so-101-thang-7-2019-

Valero MV, Zeoula LM, Moura LPPD, Júnior JBGC, Sestari BB and Prado IND (2015). Propolis extract in the diet of crossbred (1/2 Angus vs. $1 / 2$ Nellore) bulls finished in feedlot: animal performance, feed efficiency and carcass characteristics. Semina: Ciências Agrárias. 36(2): 1067-1078. DOI: https://doi.org/10.5433/1679-0359.2015v36n2p1067

Van Soest PJ, Robertson JB and Lewis BA (1991). Methods for dietary fiber, neutral detergent fiber and non-starch polysaccharides in relation to animal nutrition. Journal of Dairy Science. 74: 3583-3598. D0I: https://doi.org/10.3168/jds.S0022-0302(91)78551-2

Vu DD, Sy PV, Quyen PV and Tien NTT (2017). An assessment of technical parameters of crossbreds beef cattle in Ho Chi Minh city area. Journal of Animal Science and Technology. 78: 70-79.

Vu DD, Quyen PV, Ngan HT, Hai DV, Van NT and Tho NTB (2021). Appearance and growth performance of F1 crossbreds between Red Angus, BBB and Black Wagyu bulls with Zebu crossbred cows at Ho Chi Minh city. Journal of Animal Science and Technology, 125:13-21. Link: https://ven.org.vn/xuat-ban/tap-chi-khoa-hoc-cong-nghe-chan-nuoi-so-125-thang-7-2021- 